The New World of Retirement Income Security in America

Joseph F. Quinn, Ph.D.

Boston College

Kevin E. Cahill, Ph.D.

Sloan Center on Aging \& Work at Boston College

\author{
Joseph F. Quinn \\ Department of Economics \\ Boston College \\ Kevin E. Cahill \\ Sloan Center on Aging \& Work \\ Boston College
}

Correspondence concerning this article should be addressed to Joseph F. Quinn

Department of Economics

Boston College

Chestnut Hill MA 02467 


\begin{abstract}
We have entered a new world of retirement income security in America, with older individuals more exposed to market risk and more vulnerable to financial insecurity than prior generations. This reflects an evolution that has altered the historical vision of a financially-secure retirement supported by Social Security, a defined-benefit pension plan, and individual savings. Today, two of these three retirement income sources - pensions and savings - are absent or of modest importance for many older Americans. Retirement income security now often requires earnings from continued work later in life, which exacerbates the economic vulnerability of certain segments of the population, including persons with disabilities, the oldest-old, single women, and individuals with intermittent work histories. Because of the unprecedented aging of our society, further changes to the retirement income landscape are inevitable, but policymakers do have options to help protect the financial stability of older Americans. We can begin by promoting savings at all (especially younger) ages and by removing barriers that discourage work later in life. For individuals already on the cusp of retirement, more needs to be done to educate the public about the value of delaying the receipt of Social Security benefits. Inaction now could mean a return to the days when old age and poverty were closely linked. The negative repercussions of this outcome would extend well beyond traditional economic measures, as physical and mental health outcomes are closely tied to financial security.
\end{abstract}

Keywords: Retirement Income Security, Economics of Aging, Gradual Retirement, Vulnerable Populations, Work and Retirement 


\section{The New World of Retirement Income Security in America}

The importance of economic security among older Americans is difficult to overstate because so many outcomes are related to financial well-being, including physical and mental health. A well-established body of literature has explored the links between socioeconomic status, of which financial security is an important component, and health-related outcomes. Lower socioeconomic status is associated with increased mortality, lower health-related quality of life, lower quality of social relations, smaller social networks, and poorer psychological health, all of which can take an unmeasured toll on older Americans (American Psychological Association, 2015). With the ties between economic and health outcomes in mind, this paper focuses on one of the four priority areas of the 2015 White House Conference on Aging - the fundamental shift in the financial security of older Americans that is currently underway.

The historical vision of a financially secure retirement was a three-legged stool supported by Social Security, a defined-benefit pension plan, and individual savings. Retirement income security now often requires earnings from continued work later in life. The importance of this fourth "leg" further exposes older Americans to market forces and may exacerbate the economic vulnerability of certain segments of the population, including persons with disabilities, single women, the oldestold, and individuals with intermittent work histories.

The recent changes to retirement income security are part of an evolving process. Prior to the advent of Social Security and even through the 1950s, old age and poverty were closely linked. The poverty rates of older Americans exceeded 30 percent as recently as 1959, by far the highest of any age group at that time (DeNavas-Walt \& Proctor, 2014). The introduction and expansion of Social Security and the growth of employer pensions helped reduce the poverty rates of older Americans to below 10 percent, the lowest of any age group, and this occurred while retirement 
ages were declining steadily (Burtless \& Quinn, 2002). In the mid-1980s, the trend toward earlier retirement came to a halt, largely in response to policies and other societal changes that encouraged more work later in life. As we discuss in this paper, in the future, many older Americans will face a choice between continued work later in life or a decline in their standard of living during retirement.

Unlike in prior decades, today's changes in the retirement income landscape are taking place in a rapidly aging society. The percentage of the population aged 65 and older remained relatively constant between 1990 (12.6\%) and 2010 (13.0\%) (Werner, 2011). Since 2010, however, this percentage has increased to about $15 \%$ today and will approach $20 \%$ by 2030 (Ortman, Velkoff \& Hogan, 2014). The aging of our society will strain existing resources and further alter the retirement landscape, creating difficult choices for many older Americans.

\section{The Traditional Three-legged Stool of Retirement Income Support}

When discussing Social Security in 1938, President Roosevelt said:

Because it has become increasingly difficult for individuals to build their own security single-handed, Government must now step in and help them lay the foundation stones.... The Act does not offer anyone... an easy life — nor was it ever intended so to do. None of the sums of money paid out to individuals in assistance or in insurance will spell anything approaching abundance. But they will furnish that minimum necessity to keep a foothold; and it is the kind of protection Americans want. (Schieber, 2012, p. 124)

The clear message here is that although Social Security can provide a foundation for financial security in old age, it must be augmented by other income sources. This idea developed into the metaphor of the three-legged stool - Social Security benefits, employer pensions, and individual savings. This trio worked well in the post-WWII period and dramatically improved the financial 
well-being of retirees over time. However, recent changes in the retirement environment have weakened this stool and threaten the financial gains of many older Americans.

When poverty thresholds were developed in the 1960s and applied to prior income data, it was estimated that $35 \%$ of Americans aged 65 were living in poverty in 1959 (figure 1). This was 60 percent higher than the overall poverty rate of 22\%. Many other older Americans were surviving just above these not-at-all generous thresholds. The subsequent growth of Social Security coverage and real benefits and the development of employer sponsored defined-benefit pension plans combined to reduce dramatically the financial distress of older Americans at the lower end of the income scale, as seen in figure 1. By the early 1970s, the poverty rate of older Americans was below that of children under 18, and by 2000 it had dropped permanently below that of prime-age adults aged 18 to 64 . In 2013, only 9.5\% of older Americans were poor, which was two-thirds of the overall rate of $14.5 \%$. This has been a dramatic success story. The good news occurred not only at the lower end of the income distribution. The median income of older Americans also rose steadily and significantly, more than doubling in real terms over the past 5 decades for older American households and for important sub-categories - both married and nonmarried, and Black and White older adults (U.S. Social Security Administration [SSA], 2014a: 6).

But within this generally positive story, there is reason for concern. In 2013, for example, when fewer than $10 \%$ of older Americans fell into poverty, over 15\% had incomes below 1.25 times their poverty threshold, $21 \%$ were below 1.5 times, and 33\% were below twice their poverty line, which is the same as in the overall population (DeNavas-Walt \& Proctor: table 5). While less likely to be officially poor, older Americans are more likely to be near poor. Conversely, because of the progressive nature of nearly-universal Social Security benefits, older individuals are unlikely to be very poor; i.e., under half of the poverty line - only $2.7 \%$ vs. $6.2 \%$ 
of those aged $18-64$ and $8.8 \%$ of those under 18 . Social Security does provide a good base, but additional support is needed for financial well-being.

In addition, the overall poverty rate of older Americans conceals wide variation by gender, race, marital and household status, and age. Women aged 65 or older were $70 \%$ more likely to be poor than older men in 2013 (11.6\% vs. 6.8\%) (DeNavas-Walt \& Proctor, 2014: figure 6). Married couples were much less likely to be poor (4.4\%) than non-married men $(12.1 \%)$ and women (16.5\%) and even more so compared to never married men (15.7\%) and women (23.2\%) (U.S. SSA, 2014b: table 11.1). Poverty is much more prevalent among older racial minorities. In 2012, for example, $5.6 \%$ and $9.6 \%$ of White older men and women were poor (and $9.5 \%$ and $15.7 \%$ were below 125 percent of the poverty threshold), compared to $14.0 \%$ and $21.2 \%$ of older Black men and women (and 20.8\% and $31.6 \%$ below 125 percent) and $19.1 \%$ and $21.8 \%$ percent of older Hispanics (and 26.6\% and 31.4 below 125 percent) (U.S. SSA, 2014b, table 11.1).

Poverty also rises with age, especially for older women, from $8.9 \%$ of women aged 65-69 to $13.9 \%$ among those aged 80 or more, with nearly $23 \%$ of the latter near-poor: i.e., under $125 \%$ of their poverty threshold (U.S. SSA, 2014b: table 11.2). When certain of these demographic characteristics are combined, poverty and near poverty rates of older Americans rise dramatically. For example, while less than $10 \%$ of older Americans were poor in $2012,30 \%$ of never-married women over 80 were poor (and nearly $40 \%$ near-poor), as were $28 \%$ and $24 \%$ of all black and Hispanic women aged 80 and over (with $39 \%$ and $34 \%$ of these groups near-poor) (U.S. SSA, 2014b: tables 11.1 and 11.2).

To summarize, there have been tremendous gains in the income security of older Americans over time. Those 65 and over are now considerably less likely to be poor than other age groups. At the same time, certain subgroups (e.g., those not married, racial and ethnic 
minorities, and the oldest of the old, especially the oldest women) are very vulnerable today. And, as we will argue below, there are reasons to fear that this progress may cease or reverse, and that income insecurity among older individuals may increase.

First, what is responsible for these dramatic gains over time and can we count on them in the future? Data confirm that the traditional three legs of the stool remain important today. Receipt of Social Security is nearly universal among older Americans, with $86 \%$ of those age 65 or older receiving benefits, rising to $92 \%$ and above for those aged 70 and above, after which further delay of receipt no longer increases future benefits (U.S. SSA, 2014b: table 2.A1). More than half of older individuals receive income from assets and another $40 \%$ rely on employer pensions. Earnings, to which we will return below, are also very important in the aggregate, but decline dramatically with age, as people retire - from half of those aged 65-69 down to fewer than 9\% of those aged 80 and over. Cash public assistance (which excludes noncash food, energy, and housing assistance) is received by fewer than $4 \%$ of older individuals today (U.S. SSA, 2014b).

The prevalence of these sources has changed over time. Social Security receipt has declined slightly, reflecting later retirement and not eventual receipt, which exceeds $90 \%$ by age 75 (U.S. SSA, 2014b: Table 2:A1). Declines are seen in asset income (from about 70\% to about $50 \%$ since the $1980 \mathrm{~s}$ ) and in pension receipt (from $45 \%$ to $40 \%$ ). The prevalence of earnings has increased significantly, from $20 \%$ to $30 \%$ of aged units (married couples with at least one person aged 55 or older, and nonmarried persons aged 55 or older) over the past two decades.

However, income sources (receipt or not) can be misleading because their magnitudes are ignored. Income shares are more enlightening. In 2012, the traditional three legs of the retirement income stool provided only $63 \%$ of total cash income for older households, with nearly all the rest (34\%) coming from earnings. Asset income was received by half of older households, but 
provided only $10 \%$ of their income, and some of this may be from assets previously withdrawn from defined-contribution pension plans, which provide $17 \%$, but may be undercounted for this reason. Social Security benefits are the most important source, providing more than a third (35\%) of aggregate income among older Americans, slightly more than earnings.

Here again, these averages conceal a wide variety of very different household experiences. Figure 2 shows how vitally important Social Security is for the bottom two quintiles of older Americans, those with (2012) incomes below about $\$ 22,000-83 \%$ of their income derives from this one essential source. For the lowest quintile, most of the rest of their income comes from public assistance; individuals in the second quintile have some modest employer pension income. Social Security provides nearly two-thirds of the income in the middle quintile and $44 \%$ even in the fourth quintile. Only in the top fifth, those with incomes over $\$ 63,650$, does Social Security become relatively unimportant - approximately the same size (about 15\%) as income from assets. These are relatively wealthy older Americans most of whom are still working. Earnings provide half of their aggregate income, and more than a fifth for the fourth quintile. Employer pensions are important in the highest three quintiles, providing about $20 \%$ of their total cash income.

Income shares among older individuals have changed dramatically over time, especially earnings, which have more than doubled from $16 \%$ in 1984 to $34 \%$ today, and are still rising (figure 3). The Social Security and pension components have declined modestly since the early 1990s, and the importance of income from assets has fallen precipitously, from more than a quarter of all income in the early 1980 s to only $10 \%$ today. Public assistance has gone from important (in 1962, more important than pension income and about the same as asset income) to relatively inconsequential in the aggregate, but is still essential for those few receiving it. If 
Medicaid, Medicare and food, energy, and housing assistance were monetized and included, they would be extremely important, especially for those at the lower end of the income scale

\section{Important Changes in the Retirement Income Landscape}

Many important changes are occurring to the three traditional legs of the retirement income stool that may impact the future economic well-being of older Americans. In the world of private-sector employer pensions, researchers disagree about whether coverage is declining or increasing slightly. However, one very important phenomenon is well underway - a dramatic shift in the type of pension offered, from traditional defined-benefit (DB) to defined-contribution (DC) plans. Alicia Munnell (2014b), using the 2013 Survey of Consumer Finances, estimates that the percentage of prime-age private sector workers participating in an employer-sponsored pension on the current job, which has averaged about $50 \%$ for the last 35 years, is currently drifting down toward the low 40s. In contrast, Irena Dushi et al. (2015) estimated that, correcting for surveyresponse errors, participation rates increased slightly from $58 \%$ in 2006 to $61 \%$ in 2012 . While participation rate estimates differ, there is little disagreement about the precipitous decline in traditional DB plans in the private sector. As seen in figure 4, the percentage of those covered who have only a DB plan has fallen from $62 \%$ in 1983 (or $88 \%$ including those who have both a DB and a DC plan) to only $17 \%$ in 2013 (or to $30 \%$ including those with both). On the other hand, DC coverage, relatively rare in 1983 , has grown from $12 \%$ to $71 \%$ counting those with DC only, and from $38 \%$ to $84 \%$, counting both (Munnell, 2014b).

DC plans, such as 401(k)s and IRAs, have certain advantages. They are portable and the current value of the assets accumulated is transparent. On the other hand, DC plans often require workers to decide whether to enroll, how much to contribute (often augmented by a partial employer match), how to invest the funds, whether to withdraw assets before retirement, and 
when and how (lump-sum and/or annuity?) to withdraw the assets remaining at retirement (Munnell \& Sundén, 2004). Despite auto-enrollment provisions in about half of the plans, about 1 in 5 eligible employees still do not participate (Munnell, 2014b: figures 5 and 6). DC plans also expose workers to both market risk and to longevity risk (living longer than anticipated), two risks traditionally assumed by employers in DB plans.

In 2013, the half of working households aged 55-64 with a DC plan had an average of about $\$ 111,000$ in their $401(\mathrm{k}) \mathrm{s}$ and IRAs (to which 401(k)s are often transferred), enough to purchase a joint and survivor annuity of about \$500/month (Munnell, 2014b: page 8). But ownership of these DC assets was highly correlated with income. Two thirds of those aged 55-64 in the fourth and fifth income quintiles had 401(k)/IRA assets, averaging $\$ 132,000$ and $\$ 450,000$ respectively. DC participation fell to $22 \%$ and $48 \%$ in the lowest two quintiles, who averaged only $\$ 13,000$ and $\$ 53,000$ respectively on the eve of traditional retirement (Munnell, 2014b: table 2). For workers without pension coverage, and even for those at the lower end of the income scale who do have DC savings, this leg of the three-legged stool is non-existent or wobbly at best.

Another leg, private savings, is also inconsequential for most older Americans. The savings rate - savings as a percentage of personal disposable income - was mostly between $10 \%$ and $15 \%$ during the three decades leading up to the mid-1980s (Federal Reserve Bank of St. Louis, 2015). Savings rates then declined steadily and by the mid-2000s they reached their lowest levels since the Great Depression. Rates have increased since that time but still remain near 5\%, more than 5 percentage points below the three-decade average prior to the mid-1980s. One result of low savings rates is a low level of accumulated assets. A recent Retirement Confidence Survey found that nearly $60 \%$ of American workers (and over $40 \%$ of those aged 45 and older) own less than $\$ 25,000$ in financial assets, excluding the value of one's primary residence and defined-benefit pension plans 
(Helman, Copeland \& VanDerhei, 2015). Needless to say, this level of savings is insufficient to finance 20 years of life as a retiree without a reduction in one's standard of living.

Even Social Security, the most important income source for older Americans, especially the poorer ones, is under duress, as are two essential in-kind social safety nets, Medicare and Medicaid. Social Security (OASDI) expenditures already exceed their (non-interest) revenues and HI (Medicare part A) begins to run a deficit in the early 2020s. Without reform on the revenue and/or the expenditure side, the Social Security Trust Funds are scheduled to run out by 2033. Were this to happen, Social Security would be able to pay only 77 percent of promised benefits over the subsequent 75 years (Board of Trustees 2014: Figure II:D2).

Waiting until the Trust Funds run out and then decreasing legislated Social Security benefits by about a quarter to fit the revenue flow is an unlikely policy response. But many reform proposals do include expenditure decreases - either reductions or delays in benefits, which are equivalent. The last major reform, in 1983, which moved the "normal retirement age" from 65 to 66 , and then to 67 , did just that - it lowered the benefits received at any age.

For example, the 2010 Simpson-Bowles report, The Moment of Truth, which focused on reducing the federal budget deficit, proposed changes that would eliminate the 75-year Social Security deficit and therefore the need for drastic benefit cuts when the Trust Funds run out (National Commission, 2010). It did so mostly by lowering benefits for higher income recipients, increasing both the Full Retirement Age (FRA, now 67 for those born in 1960 or later) and the Earliest Eligibility Age (EEA, still 62 for all) in step with future gains in longevity, and lowering the annual cost-of-living adustment by using the chained CPI, a lower measurement of inflation (National Commission, 2010: page 54). All three of these proposals would lower future Social 
Security benefits. These recommendations have been ignored thus far, but they do strongly suggest that resonable reformers will include benefit cuts in their recommendations.

The Congressional Budget Office (2010) discussed 5 groups of Social Security reforms: one with numerous payroll tax increases, another with various benefit increases for low earners, and three categories that lower future benefits. The latter include changes in the formula to reduce initial benefits, increases in the FRA, and reductions in future cost-of-living adjustments. Although the $\mathrm{CBO}$ does not make policy recommendations, we note that 18 of the 30 proposals analyzed would lower future Social Security benefits (CBO, 2010: summary figure 1).

With one exception discussed below, current trends do not bode well for future retirement income security. Employer pensions in the private sector are now predominently DC plans, exposing retirees to market and longevity risk. Income from savings is declining and is almost non-existent for those most vulnerable. And even the traditional retirement bedrocks, Social Security and medical insurance benefts (Medicare and Medicaid, not discussed here) are in financial distress and reductions are being discussed.

\section{The Importance of Earnings Later In Life}

One response to these changes in the retirement landscape is to work longer and many older Americans are already doing so. The trend among men from the 1880 s to the mid-1980s was toward earlier and earlier retirement (Costa, 1998). For example, the average retirement age among men - defined here as the youngest age at which at least half of population is out of the labor force — declined steadily from more than 70 in 1910 to 63 in the early 1980s (Burtless \& Quinn 2002; Figure 11). Since then, as changes to the retirement income landscape took hold, the trend stopped 
and reversed (Quinn, Cahill \& Giandrea, 2011). Today the average retirement age among men is back to 65 , where it last was in the mid-1970s.

The break in trend since the mid-1980s is dramatic. Figure 5 shows labor force participation rates (LFPRs) for men aged 60-64 from the mid-1960s to the mid-1980s, a (regression) trend line based on those two decades (showing a decline of more than a percentage point per year), and then what actually happened since the mid-1980s. Instead of continuing the century-long decline, male LFPRs flattened out and then began to rise. A similar break in trend is also seen among older women. Prior to the 1980s, LFPRs among older women were flat, the result of two counteracting trends - the same early retirement trend that men experienced offset by the unprecedented influx of married women into the labor force following World War II. Once the early retirement trend stopped, participation rates among older women increased dramatically. The graphs are similar for younger (55-59) and older (65-69 and 70+) men and women.

Recently, the LFPRs of older Americans have leveled off during the sluggish recovery that followed the Great Recession (U.S. BLS, 2015a). An interesting question is whether this is merely a pause in the upward trend or the beginning of a new trend. The answer will depend in part on what happens to the retirement landscape in the years ahead.

The changes in labor force participation since the mid-1980s reflect how responsive older workers are to changes in the retirement environment and how willing many Americans are to delay full retirement in the interest of a more secure financial future. The positive financial impact of working longer is twofold - it increases income and possibly savings later in life and also reduces the number of years during which accumulated retirement assets are spent (CBO, 2004). 
The ways that older Americans remain in the labor force also reflect the flexibility of the U.S. labor market. Some workers delay retirement by staying longer on their careers jobs and others choose more creative ways to remain employed. Research based on the longitudinal Health and Retirement Study (HRS) demonstrates that the majority (about 60\%) of career workers transition to bridge jobs, often part-time, between career jobs and complete labor force withdrawal (Cahill, Giandrea \& Quinn, 2006, 2015, and in press; Quinn, 1999, 2010). For most Americans, retirement is not a one-time, permanent event; rather, it is a process with one or more steps along the way.

Bridge employment is one option. Another is "un-retirement." HRS data reveal that about $15 \%$ of older Americans with career jobs re-enter the labor force after retirement - a sizable minority (Cahill, Giandrea \& Quinn, 2011a). Evidence also suggests that many of these unretirement transitions are voluntary and some were anticipated prior to leaving career employment, signaling that re-entry can serve as a contingency plan if retirement income falls short of expectations or if full-time leisure turns out to be unsatisfactory (Maestas, 2010).

A third form of gradual retirement is phased retirement, in which a worker reduces hours on a current job. Attractive as this may sound, it turns out to be relatively rare, as only about $10 \%$ of older Americans with career jobs reduce their hours by at least 20 percent prior to leaving this job (Cahill, Giandrea \& Quinn, 2015). Pension rules may discourage phased retirement, particularly if benefits in a DB plan depend on one's last few years of earnings or if there are restrictions against claiming pension benefits without separating from the employer (Johnson, 2011). Notably, a recent rule change for federal employees allows for phased retirement without sacrificing pension benefits (U.S. Office of Personnel Management, 2015).

Phased retirement policies can also be a challenge for those without DB plans. Antidiscrimination rules based on age and income, while in place for good reasons, can inhibit phased 
retirement options (Johnson, 2011). They can inhibit an employer's ability to offer phased retirement because such policies may disproportionately affect older workers relative to younger ones and/or higher-compensated employees more than lower-income workers. These legal and regulatory barriers discourage phased retirement and might force older workers to switch employers in order to find the hours flexibility they desire later in life.

Another interesting dimension of American retirement patterns is the types of new jobs that older workers take, including an increase in self-employment as workers age. Among the HRS sample of career workers aged 51 to 61 in 1992, the percentage of those working who were selfemployed more than doubled over two decades, from $20 \%$ among men and $10 \%$ among women to more than 40\% and 20\% (Cahill, Giandrea \& Quinn, 2013). The reason for the increase is two-fold: the self-employed tend to remain in the labor force longer, and a substantial fraction of older workers switch from wage-and-salary career jobs to self-employed bridge jobs. Fewer workers do the reverse, so self-employment among those working increases as cohorts' age (Cahill, Giandrea \& Quinn, 2013; Zissimopoulos \& Karoly, 2009). In addition, many older Americans change occupations later in life (Johnson, Kawachi, \& Lewis, 2009). Among those who transition to bridge employment, nearly half of the men and $40 \%$ of women changed (2-digit) occupations, with more workers moving down the occupational scale than up (Cahill, Giandrea \& Quinn, 2011b). Such changes reflect the flexibility of both labor markets and workers.

The occupational flexibility of older workers may be a valuable attribute later in life. Those in physically-demanding jobs might not have the capacity to continue this kind of work into their 60s and beyond. In such situations, individuals might have no choice but to claim Social Security at the earliest age of eligibility (i.e., 62) and thereby incur a permanent reduction in monthly benefits. A change in occupation could provide workers with new options and allow more to postpone 
benefit receipt. Indeed, the reversal of the early retirement trend, along with recent declines in the claiming of Social Security benefits at age 62 (Munnell \& Chen, 2015), and the prevalence of occupational changes suggest that older workers are already taking advantage of these possibilities.

Looking forward, continued work later in life seems likely because of three trends. First, older Americans are healthier than those in the past, as seen in the increases in life expectancy. The typical 65 -year-old male and female could expect to live an additional 13 or 15 years, respectively, in 1950. In 2011, life expectancies at age 65 were nearly 18 years for men and over 20 for women (National Center for Health Statistics, 2014). At the same time, jobs have become less physically demanding. In 2014, only a fifth of the U.S. workforce was employed in physically-demanding occupations (Munnell, Cahill, Eschtruth \& Sass, 2004; U.S. BLS, 2015b). Finally, the current cohort of older workers is more educated than previous cohorts (Burtless, 2013). In 2014, over 80\% of Americans aged 65 and older completed high school and more than one quarter held a bachelor's or advanced degree, compared to just $24 \%$ and 5\% in these categories in 1965 (U.S. Census Bureau, 2015; Federal Interagency Forum on Aging-Related Statistics, 2015).

Over the past 30 years, older American workers have followed diverse paths to retirement. These paths often entail not just a change in employer but also a change in job type, from wageand-salary to self-employment and from white-collar to blue-collar, and vice versa. This flexibility, along with changes in job requirements, health and longevity, and work-related technology have reduced some barriers to work later in life. Still, for some, continued work is not an option leaving many vulnerable to financial insecurity later in life.

\section{Continued Vulnerability to Financial Insecurity Later in Life}

One immediate impact of not working and requiring Social Security income at age 62 is the permanent reduction in benefits that comes with claiming them before one's Full Retirement Age 
(FRA). For those born before 1943, this reduction was $20 \%$ if benefits were claimed at age 62 . For those born between 1943 and 1954, with a FRA of 66, the age 62 decrement is 25\%, and for those born after 1959, with a FRA of 67 , the permanent reduction will be $30 \%$ (U.S. SSA, 2015c). In the short run, the additional 10-percentage point reduction in benefits might be offset with savings or 401(k) assets. But if these alternatives run out, a reduction that seemed unimportant at age 62 may become extremely important for individuals who live the longest and who rely predominantly on Social Security benefits in old age - the most vulnerable retirees.

Both married and unmarried women are among the most vulnerable retirees because women have longer life expectancies than men (Ortman, Velkoff \& Hogan, 2014). For example, when married couples both claim Social Security benefits early, wives are more likely than husbands to bear the longer-term implications of reduced benefits. Unmarried women, without the option of claiming half of a husband's benefit, face an additional challenge, because women on average earn less than men (Blau \& Kahn, 2000). Lower lifetime earnings imply that older women are more likely to face financial insecurity in old age because their monthly Social Security benefits will be based on a history of lower earnings, even before any reduction in benefits due to claiming early.

Similarly, individuals with intermittent work histories, due to disability or other reasons, are at greater risk of financial insecurity later in life (Cahill, Giandrea \& Quinn, 2012). Social Security benefits are based on the highest 35 years of inflation-adjusted earnings (U.S. SSA, 2015a). For those without 35 years of covered earnings, an additional year of work is even more important, since it can replace a zero-earnings year in the benefit calculation.

The experience of the Great Recession highlights how difficult economic times can pose serious challenges for older workers. The official unemployment rate among older workers remained low relative to those of other age groups during and after the Great Recession, a 
seemingly bright spot for older workers in the midst of difficult times (Rix, 2013). But the official rates exclude older workers who reluctantly turned unemployment into retirement and stopped searching for work. And older workers who continued to search suffered longer spells of unemployment than younger workers. The average duration of unemployment among Americans 55 years and older far exceeded that of younger workers throughout the recovery (Rix, 2014). In March 2015, the gap between older and younger workers was 14 weeks (43 weeks among individuals aged 55+ and 29 weeks for those under age 55) (Rix, 2015). Further, the fraction of older job seekers considered long-term unemployed - for 27 or more weeks - was 45\% in 2014 compared with 22\% among younger workers (Kosanovich \& Sherman, 2015). Finally, those older workers who became reemployed over the past five years on average earned less on their new job compared with their previous job (Koenig, Trawinski \& Rix, 2015). These recent experiences highlight just how much the well-being of older workers is tied to macroeconomic conditions when earnings are the fallback if traditional income sources come up short.

Those older workers who remained employed weathered the downturn relatively well. Those unemployed, however, were hit especially hard and, unlike younger workers, had limited time to make up for any earnings shortfall. Any discussion of vulnerable populations should include those at risk of becoming unemployed in the next economic downturn. The issue of continued work is not just about who is physically able to do so, but also who is able to secure employment, especially in challenging economic times.

Macroeconomic changes also matter because older Americans with pensions are more exposed to market forces than previous generations. Given the shift from DB to DC plans noted above, workers are responsible for deciding how much to contribute and how to invest their pension assets. Missteps or bad luck along the way can lead to economic hardship later. Some will 
contribute too little, others may not invest wisely, and still others will borrow against their assets or withdraw them before reaching age 591/2, which triggers a 10 -percent tax penalty over and above the income taxes paid on the amount withdrawn (U.S. Internal Revenue Service, 2015). And of course equity markets can decline, sometimes precipitously. Each of these factors can impact the level of assets available when it comes time to retire.

Through DC plans, employers have transferred to workers both investment risk and longevity risk (Munnell, 2015). Theoretically, individuals can insure against longevity risk by buying an annuity with all or some of one's DC assets, but relatively few do. Annuity markets are still thin and not well understood, and others may not want to risk losing through an early death assets that could have been bequeathed to others (Brown, Kling, Mullainathan \& Wrobel, 2008). Further, older workers' increased exposure to market risk comes at a time when equity markets are volatile. The Dow Jones Industrial Average, a barometer of equity market conditions, dropped $25 \%$ or more and then rebounded on three separate occasions during the past 15 years (Wall Street Journal, 2014). If an older worker were heavily invested in equities just prior to any of these periods, their assets available for retirement would have declined substantially. Even during an upswing, there is the prospect that the market can drop at any time. This potential for loss exacerbates an already uncertain landscape for older Americans.

One mitigating factor is that health insurance prior to age 65 is less tied to employment because of the Patient Protection and Affordable Care Act (ACA) (Kaiser, 2013). Before the ACA, an older American with pre-existing medical conditions would strongly prefer an employer with good health insurance coverage because purchasing an individual policy in the private market could be impossible or prohibitively expensive. Such situations could lock individuals into their current employers or push them into other jobs with adequate healthcare. The ACA and access to health 
insurance coverage regardless of pre-existing conditions reduce the importance of these employer insurance issues and enables more work options for older Americans.

\section{Options to Mitigate the Impacts of the New World of Retirement Income Security}

The challenge for society is to implement policies that can mitigate the adverse consequences of today's changing retirement income world. Increasing the Delayed Retirement Credit (DRC) so that Social Security is now close to actuarially fair for the average worker was an important change (U.S. SSA, 2015b). A logical next step is to further encourage work later in life for those who can and want to do so. The following strategies can harness older workers' interest in remaining in the labor force.

1) Remove barriers to phased retirement. As noted above, workplace anti-discrimination laws with respect to age and income may deter employers from offering formal phased retirement programs and may obstruct arrangements in which individuals receive pension benefits while working reduced hours with their employer. Policymakers should explore exemptions to these laws for the purpose of enabling phased retirement.

2) Educate the public about the Delayed Retirement Credit, the reward for delaying Social Security receipt beyond the early retirement age. Doing so will help counter the common misperception that the Full Retirement Age (FRA) is a recommendation about when individuals should stop working. Delaying receipt until age 70 maximizes annual benefits and provides inflation-protected insurance against living longer than expected. Social Security is the primary source of retirement income for many older Americans and the annual benefit increases that come with delayed receipt can be critical for those living longest, and can reduce the probability of slipping into poverty and having to rely on social assistance programs. 
3) Remove the Earnings Test below the FRA. The Earnings Test, as understood and often misunderstood by the public, was a barrier to continued work above the FRA when it existed and its removal provided an economic incentive to remain working. Currently, between one third and one half of all workers claim benefits at age 62 and therefore face the Earnings Test, which lowers benefits as one earns more and can discourage work and asset accumulation, until they reach the FRA (Haaga \& Johnson, 2012; Munnell \& Chen, 2015).

4) Promote workplace flexibility for older workers. Many workers want to remain in the labor force but with fewer hours and/or less responsibility than they had on career jobs. Gradual or partial retirement can be beneficial to workers, firms and society. One option is to foster communication about work options that are already available to employees but not widely utilized (Center on Aging \& Work, 2015). By promoting better communication among managers and workers, policymakers could address both employees' barriers to flexible work arrangements (e.g., being unaware of options available or perceiving an adverse impact on one's career) as well as managers' concerns (e.g., scheduling difficulties or potential abuse of policies by employees). A recent study found that a randomly assigned straightforward intervention focusing on employeemanager communications about workplace flexibility positively influenced employees' work and retirement expectations, as the intervention increased the number of employees who planned to remain with their current employer until retirement (Cahill, James \& Pitt-Catsouphes, 2015).

To increase retirement options for all, policymakers should promote additional savings, particularly among the young but even among those nearing retirement. For example:

1) Promote opt-out defined-contribution plans with pre-set contribution levels. Research shows that more workers will participate if they have to opt-out rather than opt-in, even when both are easily done, and that many view the default contribution rate as a recommendation for an 
appropriate amount (Lusardi \& Mitchell, 2011; Munnell, 2015; Yakoboski, 2011). Some who do not participate miss out on employer matching contributions. The opt-out structure increases savings while maintaining individual choice.

2) Promote savings among all age groups. As noted above, the savings rate in America declined precipitously throughout the 1980s and 1990s. A national effort to teach citizens about the value of savings and the concept of compound interest could reduce financial hardships in old age.

Two additional policy recommendations are worth mentioning. First, policymakers should address Social Security’s long-run finances. Recently, the size of the 75-year unfunded liability rose from less than $2 \%$ (in 2010) to nearly $3 \%$ of Social Security taxable earnings, and the date at which the Trust Fund is predicted to be depleted is now within two decades (2033) (Munnell 2014a). There are many reasonable ways to balance increases in Social Security revenues and decreases in expenditures. Social Security is the primary lifeline preventing a sizable fraction of the older Americans from falling into poverty; thus, its fiscal strength should be a top priority.

Second, in recent years home equity has been used by some to supplement income late in life, through reverse mortgages (Munnell, 2015). Like buying an annuity with assets from a defined-contribution pension, there are risks. If the recipient dies soon, then an important asset (often the largest asset) could be lost instead of bequeathed. Conversely, like Social Security, the home can provide income for life, while the aged person continues to live in it, and this could be very helpful when other sources of income are inadequate and other assets lacking. This market is still thin. Policymakers could help by making this option and the details known to those who should be considering it.

The United States is fortunate to have an older workforce with higher levels of education than previous generations, jobs that are by and large less physically demanding than in the past, and 
a flexible labor market that enables diverse and creative pathways to retirement. Financial incentives in public and private pension plans that used to discourage work have either been eliminated (as in Social Security) or are diminished in importance, as the prevalence of DB pensions has declined. The relative attractiveness of work and leisure later in life has shifted in favor of work, and policymakers can help continue this trend. Continued work later in life not only helps individuals by lowering the risk of financial insecurity, but also helps employers by generating a larger pool of experienced workers, and benefits society as more individuals produce goods and service to be consumed by an aging population. While not losing sight of those for whom continued work is not an option, additional work later in life, already well underway, is a prudent strategy to reduce the financial vulnerability of older Americans, and a critical step toward maintaining and even improving the mental and physical health outcomes of older Americans in the years ahead. 


\section{References}

American Psychological Association (2015). Fact Sheet: Age and Socioeconomic Status.

Available at: http://www.apa.org/pi/ses/resources/publications/factsheet-age.aspx.

Blau, F.D. \& Kahn, L. M. (2000). Gender Differences in Pay. Working Paper \#7732. Cambridge, MA: National Bureau of Economic Research.

Board of Trustees of OASDI. (2014). The 2014 annual report of the board of trustees of the federal old-age and survivors insurance and federal disability insurance trust funds. Washington, DC: U.S. Government Printing Office.

Brown, J. R., Kling, J. R. Mullainathan, S. \& Wrobel, M. V. (2008). Why don't people insure late-life consumption? A framing explanation of the under-annuitization puzzle. American Economic Review, 98(2), 304-09.

Burtless, G. (2013). Can educational attainment explain the rise in labor force participation at older ages? Issue Brief 13-13. Chestnut Hill, MA: The Center for Retirement Research at Boston College.

Burtless, G. \& Quinn, J. F. (2002). Is working longer the answer for an aging workforce? Issue Brief No. 11. Chestnut Hill, MA: The Center for Retirement Research at Boston College.

Cahill, K. E., Giandrea, M. D. \& Quinn, J. F. (2006). Retirement patterns from career employment, The Gerontologist, 46(4), 514-523.

Cahill, K. E., Giandrea, M. D. \& Quinn, J. F. (2011a). Reentering the labor force after retirement Monthly Labor Review, 134(6), 34-42.

Cahill, K. E., Giandrea, M. D. \& Quinn, J. F. (2011b). How does occupational status impact bridge job prevalence? Working Paper \#447. Washington, DC: U.S. Bureau of Labor Statistics. 
Cahill, K. E., Giandrea, M. D. \& Quinn, J. F. (2012). Older workers and short-term jobs: employment patterns and determinants. Monthly Labor Review, 135(5), 19-32.

Cahill, K. E., Giandrea, M. D. \& Quinn, J. F. (2013). New evidence on self-employment transitions among older Americans with career jobs. Working Paper \#463. Washington, DC: U.S. Bureau of Labor Statistics.

Cahill, K. E., Giandrea, M. D. \& Quinn, J. F. (2015). Retirement patterns and the macroeconomy, 1992 - 2010: the prevalence and determinants of bridge jobs, phased retirement, and reentry among three recent cohorts of older Americans. The Gerontologist, 55(3), 384403; doi: 10.1093/geront/gnt146.

Cahill, K. E., Giandrea, M. D. \& Quinn, J. F. (in press). Evolving patterns of work and retirement. In L. George \& K. Ferraro (Eds.), The Handbook of Aging and the Social Sciences (8th Edition). New York, NY: Elsevier.

Cahill, K. E., James, J. B. \& Pitt-Catsouphes, M. (2015). The impact of a randomly-assigned time and place management initiative on work and retirement expectations. Work, Aging and Retirement, 1(3); doi: 10.1093/worker/wav012.

Center on Aging \& Work. (2015). Barriers to workplace flexibility (WF). Retrieved from http://workplaceflexibility.bc.edu/Barriers\#encourage

Congressional Budget Office. (2004). Retirement age and the need for saving. Washington, DC: U.S. Government Printing Office.

Congressional Budget Office. (2009). CBO's long-term projections for social security.

Washington, DC: U.S. Government Printing Office.

Congressional Budget Office. (2010). Social Secrity Policy Options. Washington, DC: U.S. Government Printing Office. Retrieved from https://www.cbo.gov/publication/21547 
Costa, D. (1998). The evolution of retirement: An American economic history, 1880-1990. Chicago, IL: University of Chicago Press.

DeNavas-Walt, C. \& Proctor, B. D. (2014). Income and poverty in the United States: 2013. Washington, DC: U.S. Census Bureau. Retrieved from https://www.census.gov/content/dam/Census/library/publications/2014/demo/p60-249.pdf

Dushi, I., Iams, H. M. \& Lichtenstein, J. (2015). Retirement plan coverage by firm size: An update. Social Security Bulletin, 75(2), 41-55.

Federal Interagency Forum on Aging-Related Statistics. (2015). Retrieved from http://www.agingstats.gov/main_site/data/2012_documents/population.aspx.

Federal Reserve Bank of St. Louis. (2015). Personal saving as a percentage of disposable personal income. St. Louis, MO: Federal Reserve Bank of St. Louis. Retrieved from http://research.stlouisfed.org/fred2/series/A072RC1Q156SBEA.

Haaga, O. \& Johnson, W. (2012). Social Security Claiming: Trends and Business Cycle Effects. Retirement Policy Discussion Paper Series. Washington, DC: The Urban Institute.

Helman, R., Copeland, C. \& VanDerhei, J. (2015). The 2015 retirement confidence survey: Having a retirement savings plan a key factor in Americans' retirement confidence. Issue Brief No. 413. Washington, DC: Employee Benefit Research Institute. Retrieved from http://www.ebri.org/pdf/briefspdf/EBRI_IB_413_Apr15_RCS-2015.pdf

Johnson, R. W. (2011). Phased retirement and workplace flexibility for older adults: opportunities and challenges. The ANNALS of the American Academy of Political and Social Science, 638(1), 68-85.

Johnson, R. W., Kawachi, J. \& Lewis, E. K. (2009). Older workers on the move: Recareering in later life. Research Report No. 2009-08. Washington, DC: AARP Public Policy Institute. 
Kaiser Family Foundation. (2013). Summary of the Affordable Care Act. Washington, D.C.: The Henry J. Kaiser Family Foundation. Retrieved from http://kaiserfamilyfoundation.files.wordpress.com/2011/04/8061-021.pdf.

Kasonovich, K. \& Sherman, T. E. (2015). Trends in long-term unemployment. Spotlight on Statistics. Washington, DC: U.S. Bureau of Labor Statistics. Retrieved from http:/www.bls.gov/spotlight/2015/long-term-unemployment/pdf/long-termunemployment.pdf.

Koenig, G, Trawinski, L. \& Rix, S. (2015). The long road back: Struggling to find work after unemployment. Washington, DC: AARP Public Policy Institute. Retrieved from http://www.aarp.org/content/dam/aarp/ppi/2015-03/The-Long-Road-Back_INSIGHT.pdf.

Lusardi, A. \& Mitchell, O. S. (2011). Financial literacy and planning: Implications for retirement wellbeing. Working Paper \#17078. Cambridge, MA: National Bureau of Economic Research.

Maestas, N. (2010). Back to work: Expectations and realizations of work after retirement. Journal of Human Resources, 45(3), 718-748.

Munnell, A. H. (2014a). Social Security's Financial Outlook: The 2014 Report in Perspective. Issue Brief No. 14-12. Chestnut Hill, MA: The Center for Retirement Research at Boston College.

Munnell, A. H. (2014b). 401(k)/IRA Holdings in 2013: An Update from the SCF. Issue Brief No. 14-15. Chestnut Hill, MA: The Center for Retirement Research at Boston College. Munnell, A. H. (2015). Falling Short: The Coming Retirement Crisis and What to Do About It. Issue Brief No. 15-7. Chestnut Hill, MA: The Center for Retirement Research at Boston College. 
Munnell, A. H., Cahill, K. E., Eschtruth, A. \& Sass, S. A. (2004). The graying of Massachusetts: Aging, the new rules of retirement, and the changing workforce. Boston, MA: The Massachusetts Institute for a New Commonwealth.

Munnell, A. H. \& Chen, A. (2015). Trends in Social Security claiming. Issue Brief No. 15-8. Chestnut Hill, MA: The Center for Retirement Research at Boston College.

Munnell, A. H. \& Sundén, A. (2004). Coming up short: The challenge of 401(k) plans. Washington, D.C.: Brookings Institution Press.

National Center for Health Statistics. (2014). Health, United States, 2013: With special feature on prescription drugs. Hyattsville, MD: U.S. Department of Health and Human Services. Retrieved from http://www.cdc.gov/nchs/data/hus/2013/018.pdf.

National Commission on Fiscal Responsibility and Reform (2010). The Moment of Truth. Retrieved from http://www.fiscalcommission.gov/sites/fiscalcommission.gov/files/documents/TheMoment ofTruth12_1_2010.pdf

Ortman, J. M., Velkoff, V. A. \& Hogan, H. (2014). An aging nation: The older population in the United States. Current Population Reports, P25-1140. Washington, DC: U.S. Census Bureau. Retrieved from http://www.census.gov/prod/2014pubs/p25-1140.pdf

Quinn, J. F. (1999). Retirement Patterns and Bridge Jobs in the 1990s. Issue Brief No. 206. Washington, DC: Employee Benefit Research Institute, 1-23.

Quinn, J. F. (2010). Work, retirement, and the encore career: Elders and the future of the American workforce. Generations, 34(3), 45-55.

Quinn, J. F., Cahill, K. E. \& Giandrea, M. D. (2011). Early Retirement: The Dawn of a New Era? Policy Brief. New York, NY: TIAA-CREF Institute. 
Rix, S. E. (2013). The employment situation, December 2012: Five years after the start of the Great Recession. Fact Sheet No. 276. Washington, DC: AARP Public Policy Institute. Rix, S. E. (2014). The employment situation, January 2014, and a look back at 2013: Fewer older workers unemployed, more out of the labor force. Fact Sheet No. 302. Washington, DC: AARP Public Policy Institute.

Rix, S. E. (2015). The employment situation, March 2015: Employment Growth Slows. Fact Sheet No. 326. Washington, DC: AARP Public Policy Institute.

Schieber, S. J. (2012). The predictable surprise: The unraveling of the U.S. retirement system. New York, NY: Oxford University Press.

U.S. Bureau of Labor Statistics (2015a). Labor Force Participation Rates by Single Year of Age and Sex, 1965-2014 (unpublished).

U.S. Bureau of Labor Statistics. (2015b). Employment and Earnings. Retrieved from http://www.bls.gov/opub/ee/2015/cps/annual.htm\#empstat

U.S. Census Bureau. (2014). Income and Poverty in the in the United States: 2013. Retrieved from https:/www.census.gov/content/dam/Census/library/publications/2014/demo/p60249.pdf

U.S. Census Bureau. (2015). Educational Attainment in the United States: 2014. Retrieved from http://www.census.gov/hhes/socdemo/education/

U.S. Internal Revenue Service. (2015). Topic 558 - Additional Tax on Early Distributions from Retirement Plans Other than IRAs. Retrieved from http://www.irs.gov/taxtopics/tc558.html

U.S. Office of Personnel Management. (2015). Phased Retirement. Retrieved from http://www.opm.gov/retirement-services/phased-retirement/ 
U.S. Social Security Administration. (2014a). Income of the Aged Chartbook: 2012.

Retrieved from http://www.ssa.gov/policy/docs/chartbooks/income_aged/.

U.S. Social Security Administration. (2014b). Income of the Population 55 and Older: 2012.

Retrieved from http://www.ssa.gov/policy/docs/statcomps/income_pop55/

U.S. Social Security Administration. (2015a). Social Security Benefit Amounts.

Retrieved from http://www.ssa.gov/oact/cola/Benefits.html

U.S. Social Security Administration. (2015b). Retirement Planner: Delayed Retirement Credits.

Retrieved from http://www.ssa.gov/planners/retire/delayret.html

U.S. Social Security Administration. (2015c). Early or Late Retirement?

Retrieved from http://www.ssa.gov/OACT/quickcalc/early_late.html

Wall Street Journal. (2014). Dow Jones Industrial Average - Historical prices. New York: NY:

Dow Jones \& Company. Retrieved from quotes.wsj.com/DJIA/Index-historical-prices\#.

Werner, C. A. (2011). The Older Population: 2010. 2010 Census Briefs. Washington, DC:

U.S. Census Bureau. Retrieved from

http://www.census.gov/prod/cen2010/briefs/c2010br-09.pdf.

Yakoboski, P. J. (2011). Rethinking defined contribution retirement plan design: Plan sponsor perspectives. Policy Brief. New York, NY: TIAA-CREF Institute.

Zissimopoulos, J. M. \& Karoly, L. A. (2009). Labor-force dynamics at older ages: Movements into self-employment for workers and nonworkers. Research on Aging, 31(1), 89-111. 


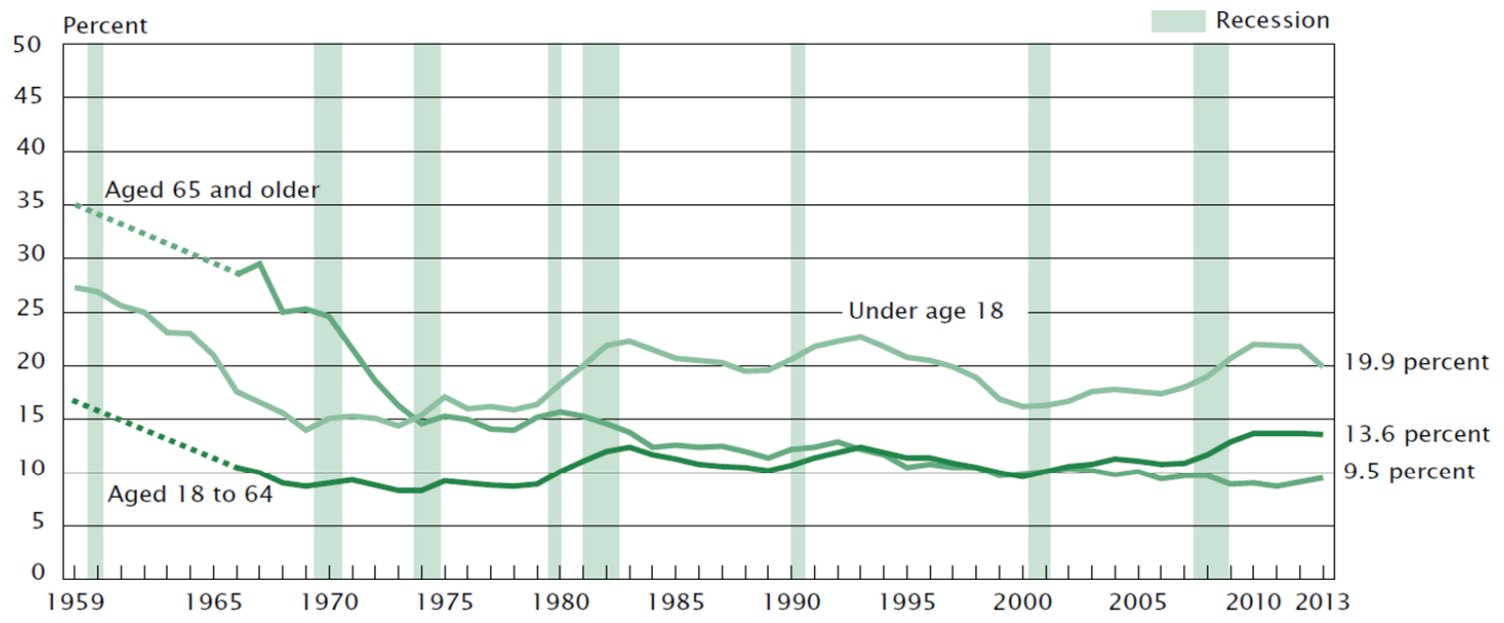

Source: U.S. Census Bureau (2014). Income and Poverty in the in the United States: 2013 : Figure 5. Available at: https:/www.census.gov/content/dam/Census/library/publications/2014/demo/p60-249.pdf.

Figure 1. Poverty rates by age, 1959 to 2013. 

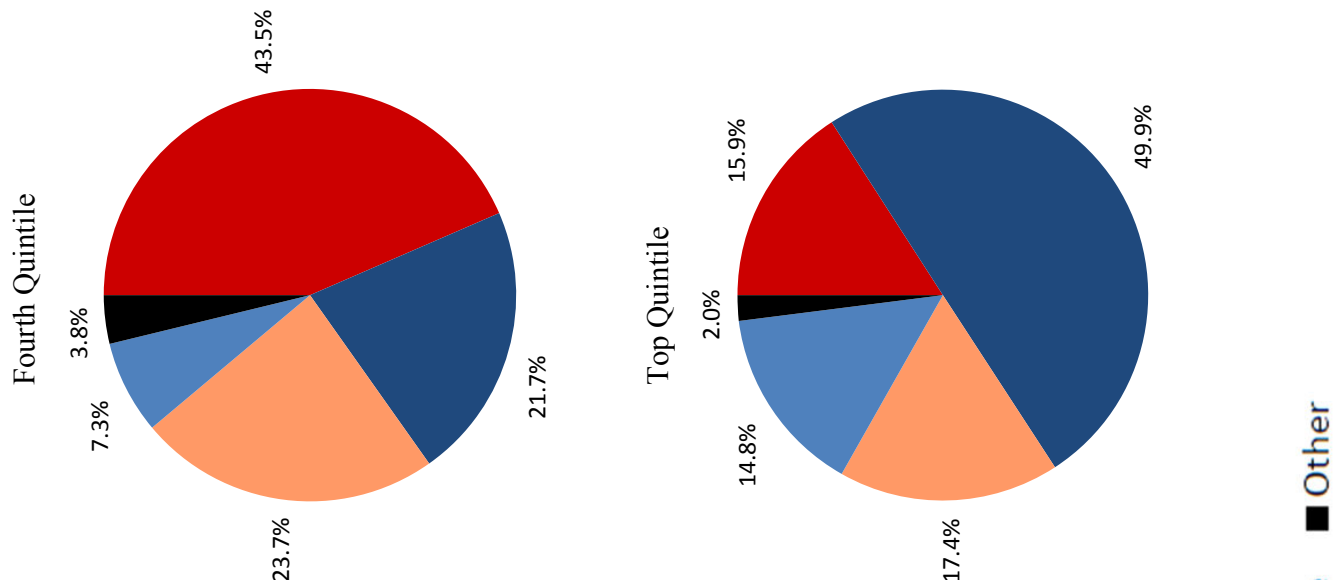

告
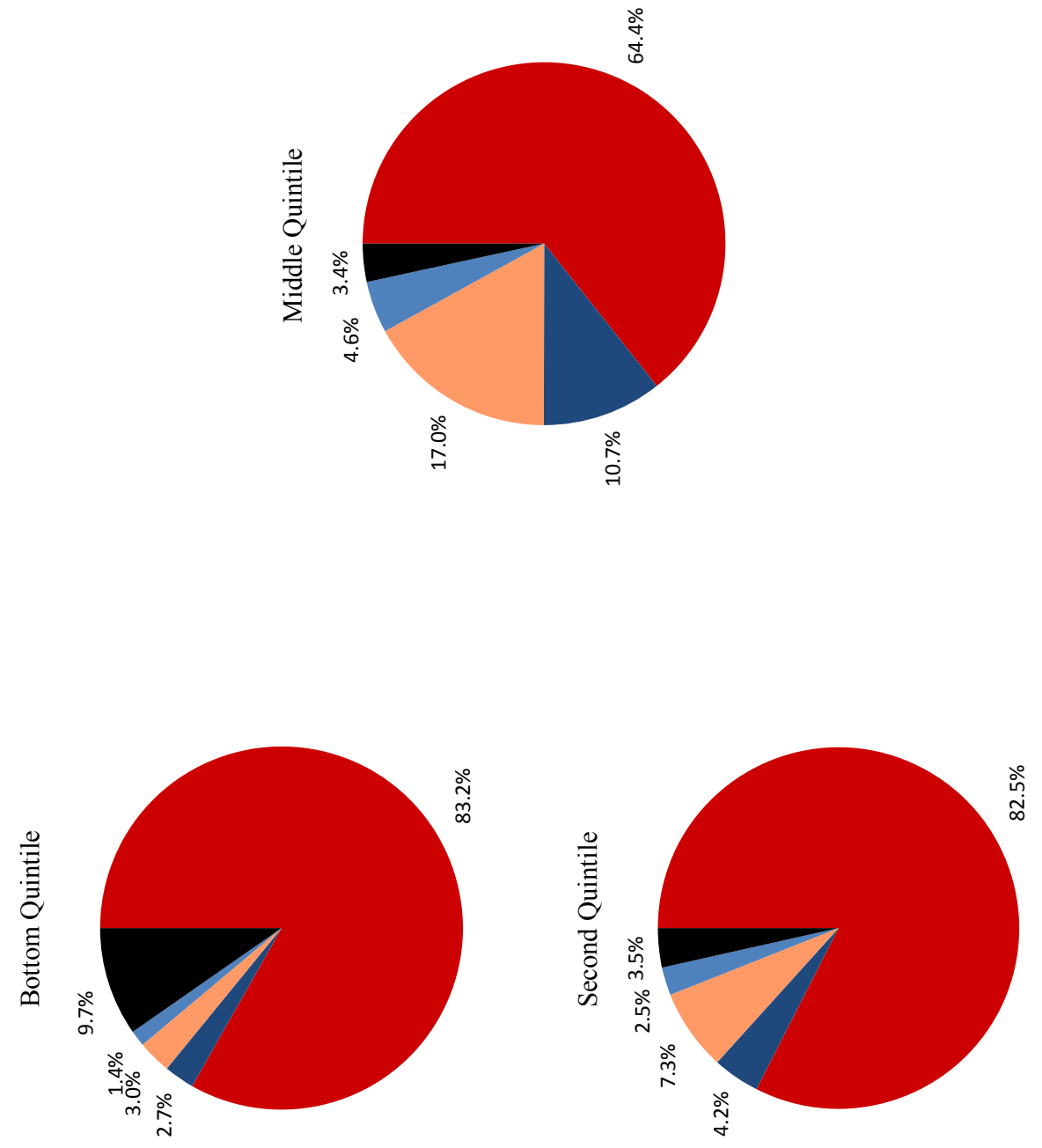

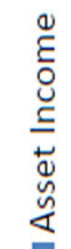

๕.

is

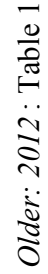

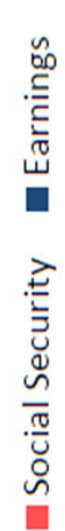




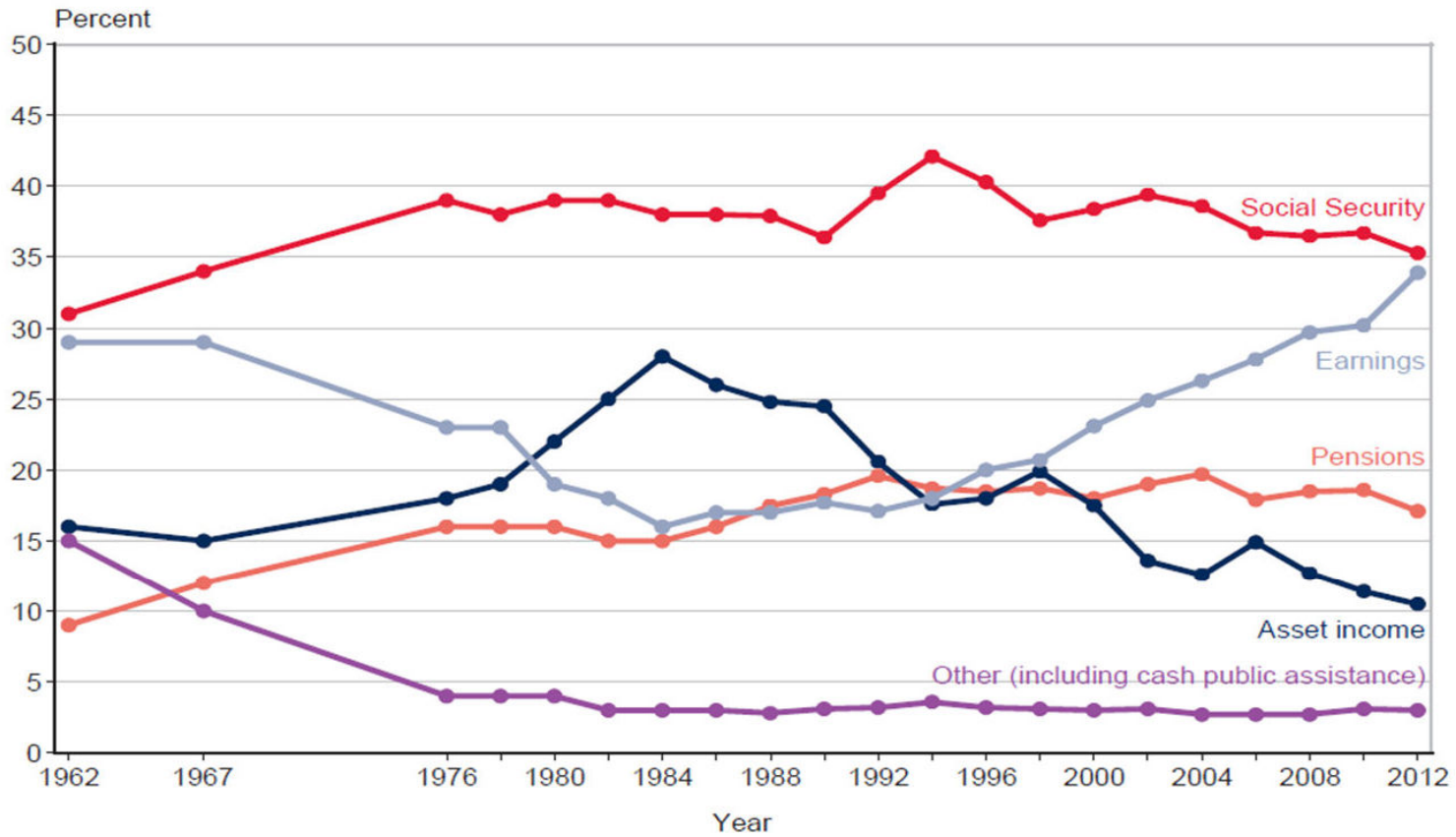

Source: U.S. Social Security Administration (2014a). Income of the Aged Chartbook: 2012: p. 18. Available at: http://www.ssa.gov/policy/docs/chartbooks/income_aged/.

Figure 3. Shares of aggregate income, by source, selected years. 


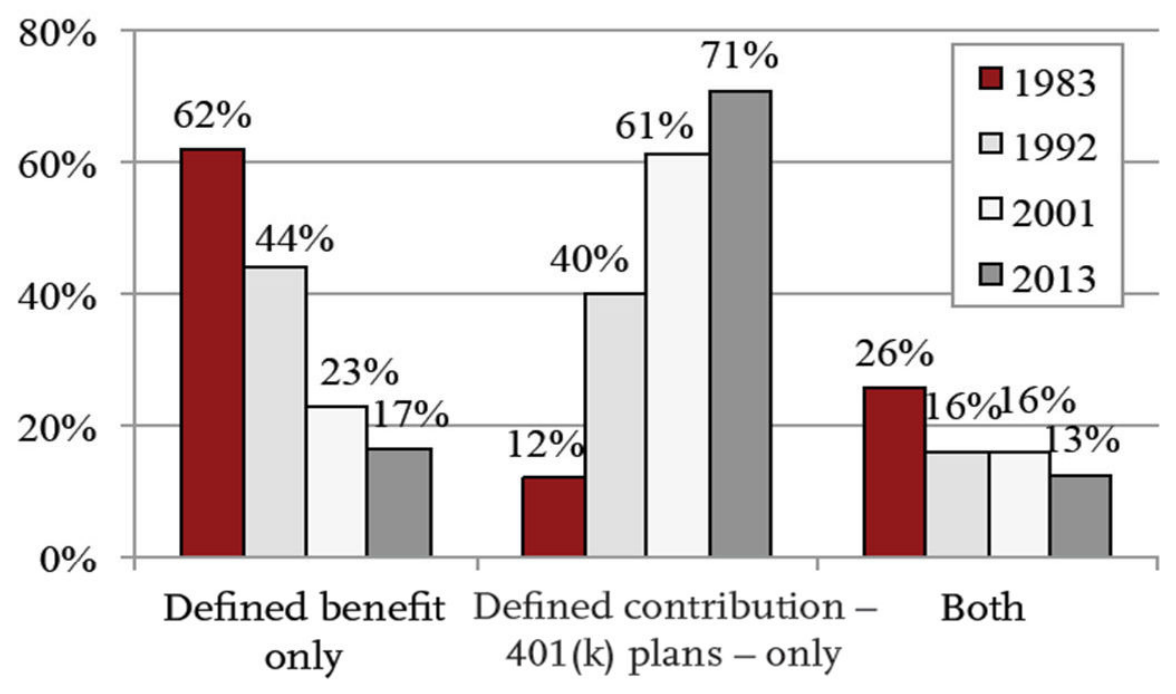

Source: Munnell, A. H (2014b). 401 (k)/IRA Holdings in 2013: An Update from the SCF. Issue Brief No. 14-15. Chestnut Hill, MA: The Center for Retirement Research at Boston College: Figure 3. Available at: http://crr.bc.edu/wp-content/uploads/2014/09/IB_14-151.pdf.

Figure 4. Workers with pension coverage by type of plan, 1983, 1992, 2001, and 2013. 
Males, Aged 60-64

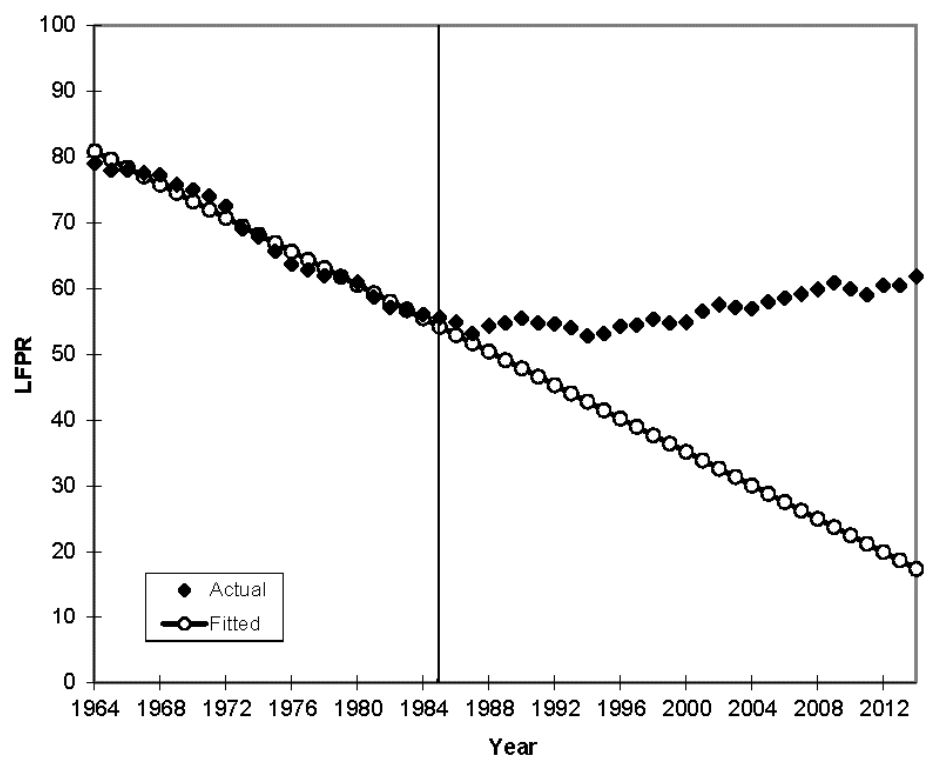

Females, Aged 60-64

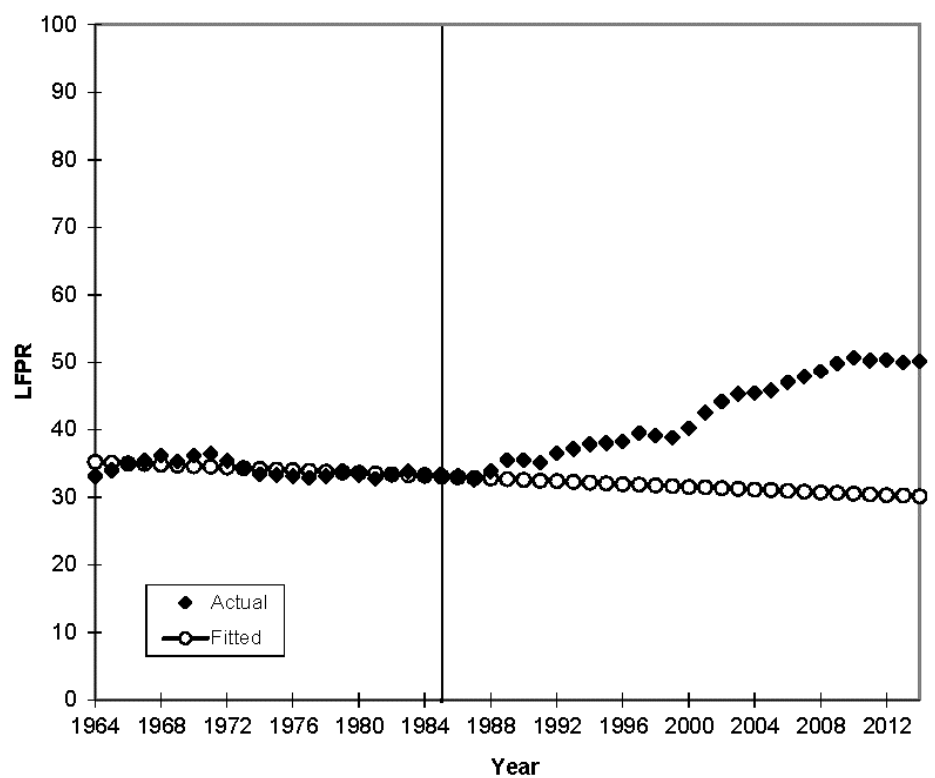

Source : U.S. Bureau of Labor Statistics. Employment and Earnings. Available at: http://www.bls.gov/opub/ee/2015/cps/annual.htm\#empstat.

Figure 5. Labor force participation rates, actual and fitted values, by gender, 1964-2014. 